\title{
Place-Names from Surnames: Maryland ${ }^{1}$
}

\author{
HAMILL KENNY
}

$\Upsilon^{1}$

HE GAZETTEERS of an old region like Maryland (chartered in 1632 ) present the researcher with an excess of place-names derived from surnames. Though he may not necessarily know the local history of these names, a casual survey will show him that, of the 3,183 entries in Gaz. Md. 1904, ${ }^{2}$ 1,731 (54 per cent) are probably derived from surnames. If he looks more critically, weighing in each case the possibility of ambiguity, he will see that of these 1,731 probable surname derivatives 1,062 (61 per cent) are almost certainly derived from surnames. Of the remaining 669 there are 457 that may or may not contain surnames. This is because they are potentially ambiguous, and (instead of surnames) perhaps embody given names (e.g., Helen, Henryton), or adjectives and common nouns (e.g., Fairtown, Hill Point, Wallville), or the names of certain countries and towns (e.g., Holland Island, Winchester Creek) identical to surnames in spelling. Left over are 212 names

${ }^{1}$ Here and there, using abbreviations, I cite the following: Archives (Archives of Maryland, Baltimore, I, 1883 -); Coordinates 1962 (Maryland Manual of Coordinates 1962); Ekwall (E. Ekwall, Concise Oxford Dictionary of English Place-Names, 4th ed., 1960); Gannett (H. Gannett, Origin of Certain Place Names in the United States, 2nd ed., 1905); Gaz. Md. 1904 (H. Gannett, Gazetteer of Maryland ... 1904); Gaz. Md. 1941 (Gazetteer of Maryland [Md. State Planning Commission] 1941); Heads 1790 (Heads of Families First Census of the United States 1790 Maryland); Mawer (A. Mawer, The Chief Elements Used in English PlaceNames ... Cambridge, 1924); Ramsay (R. L. Ramsay, A. W. Read, Introduction to a Survey of Missouri Place-Names/Univ. of Mo. Studies, IX. 1, 1934/); Reaney (P. H. Reaney, A Dictionary of British Surnames, London, 1958); TDr (Directories of the Chesapeake and Potomac Telephone Co. of Md.).

Other abbreviations are Co. (County); Lat. (Latin); ME (Middle English); OE (Old English); OF (Old French); ON (Old Norse and Scandinavian); p.v. (post village); v. (village).

2 Gaz. Md. 1904 gives only half of the 6,385 names that are listed in Gaz. Md. 1941 (see "The Problem of a National Gazetteer," Names 1: 4 (December, 1953), 236-237). However, I consider the 1904 gazetteer adequate for the scope of this article. 
(e.g., Pungers Creek, Rover, Towsers Branch) that look as though they contain surnames yet are obscure.

Almost any kind of systematic effort to arrange these names would enlighten the study of them. They could be classified from the standpoint of their syntax (e.g., surname plus generic: Bentley Cove). They could be classified by the natural features they name (e.g., Hollin Cliff, Holton Point). They could be classified by some common aspect of the lives of the men whose surnames they bear (e.g., Braddock Run, for General Edward Braddock, whom the French and Indians killed in 1755; Mayo, for Commodore Isaac Mayo, outstanding naval officer in the War of 1812). Arrangements like these would perhaps be little more than classification for classification's sake. Since, however, dozens of Maryland's placenames embody local surnames that have come from English placenames, there is one kind of classification that might be meaningful. This would be to single out these English local surname derivatives and arrange them according to the Anglo-Saxon place-name elements they contain (e.g., AppleTON, BerkLEY, BradSHAW).

So typical are these Anglo-Saxon place-name elements that, were it not for the possible ambiguities, almost all of the Maryland place-names containing them could be regarded as having come from English local surnames. These English local surnames, in turn, arose either from existing English place-names (e.g., Chester /Cheshire/) or from familiar English topographical features (e.g., LEE/OE $l \bar{e} a h /)$. This means that, in each authentic instance, there is the cycle of an English place-name like Scarborough (OE burh) giving rise to a local surname (Scarborough ${ }^{3}$ ) which in Maryland designates a new place (Scarboro Creek). ${ }^{4}$ Similar cases are legion. So, however, are the ambiguities. Gunby, Md., for example, may be from the local surname, Gunby. On the other hand, like the local surname, it could come from Gunby, the English village. For a variety of reasons it is difficult to be sure about some of these names. Massey (Massey, Massey Creek: Kent Co.), for instance, does not contain EG "island," but comes from a (French) pet form of Matthew (Reaney). Linchester and Tolchester (as in

3 TDr Harford Co. lists two Scarboros, 27 Scarboroughs. TDr Somerset and Worcester Cos. lists nine Scarboroughs, no Scarboro.

4 There are two Scarboro ${ }^{\&}(\mathrm{v}$.), one in Harford Co., one in Worcester Co. There are two Scarboro Creeks, both in Worcester Co. 
Tolchester Beach) are not from surnames, do not have an organic CEASTER, indeed are probably artificial..$^{5}$ Hasty (in Hasty Point) is not a local surname from $\overline{\mathbf{E}} G$ "island," but a descriptive surname from the adjective hasty. These exceptions, however, do not lessen the probability that what looks like an OE element in a Maryland place-name usually is. The point is that one must be always suspicious.

\section{The Chief Elements}

The most common Anglo-Saxon (and ON) place-name elements (see Mawer) in Maryland place-names from English local surnames are AECER (Whitaker); BROM (Broome Island); BROC (Bolingbroke Creek, ${ }^{6}$ Brookeville); BURH (Goldsboro Creek, Greenbury Point); BURNA (Claiborne, Colbourne); BY /ON byr/ (Bynum, ${ }^{7}$ Bynum Run, Lusbys); CEASTER (Winchester ${ }^{8}$ ); DAEL (Truesdell Heights); DENU (Hayden, Woodensburg); DUN / confused with DENU and TUN/ (Doncaster, Snowdens Saw Mill Branch, Weldon) EG, IEEG /ON ey/ (Loney's Lane Station, Veazey Neck); FELD (Greenfield Mills, Hollofield ${ }^{9}$ ); ON fell, fiall (Fells Point ?); FORD (Harford, Whiteford ${ }^{10}$ ); GEARD (Woodyard ${ }^{11}$ ); GEAT (Wingate); HAM (Cottingham Ferry, Lanham /Lanhams $/{ }^{12}$ ); HEALL (Halls, Halls Hill); ON holmr, holmi (Chisholm Run); HYRST (Gaz. Md. 1941: Hurst Creek); ON kiarr, ME kerr (Walker, Walkers Switch, Walkersville); LAND (Garland, Holland Point, Rowlandsville); LEAH (Hartley, Ridgley Cove, Whiteleysburg); MOR (Moore

${ }^{5}$ Linchester, about three miles northeast of the point where the boundary lines of Dorchester and Caroline Cos. meet, is probably a combination of $\ldots \operatorname{lin}(e)$ and ...chester. Tolchester Beach is perhaps from the Tol- of William Tolson ("Tolchester Farm," patented in 1762) and chester.

6 Archives (XLIX, 1665, p. 13) mentions a Talbot Co. "Creeke called Bullen Brooke." The date seems to rule out, as namesake, Henry St. John Bolingbroke (1678-1671), First Viscount, who became chancellor of the exchequer. Cf. Bolingbroke, Lincolnshire, England. Note: Chancellor(s) Point, Talbot Co.; Bolinbroke Creek (Talbot), Gaz. Md. 1941.

7 See Elsdon C. Smith, American Surnames (Phila., 1969), p. 189.

8 TDr Anne Arundel: four Winchesters.

9 Gaz. Md. 1941 : Hollofield (v.), Baltimore Co., Howard Co. TDr Balt.: "Hollofield and Dogwood Rd."

10 TDr Harford Co.: nine Whiteford $\mathrm{s}^{\mathrm{s}}$, all of Whiteford, Md.

11 TDr D. C., Balt. Suburbs: six Woodyards; TDr Baltimore: seven Woodyards.

12 TDr Baltimore: 31 Lanham $^{\text {s. }}$ 
Knob, Moors Run ${ }^{13}$ ); POL (Poolesville ${ }^{14}$ ); PORT (Newport Bay $^{15}$ ); ROD (Rhode River); SCEAGA (Shaw Bay, ${ }^{16}$ Briscoe Creek ${ }^{17}$ ); STAN (Stanley Run); WIELLE, WIELLA (Cromwell, Wellhams ${ }^{18}$ ); WORTH, WEORTH (Bedsworth); WUDU (Harwood, Greenwood Creek, Kaywood ${ }^{19}$ ).

There remain, in addition to these, TUN (-ton, -town) and $W \bar{I} C$ (-wic/k/; -ville). Each deserves separate attention:

(I) TUN (-ton, -town) in the place-names of England appears almost solely as -ton. In Ekwall there are only six place-names with -town and seven with Town(e). In Gaz. Md. 1904, however, there are 92 place-names with -ton and 48 with -town. Many of the Maryland place-names with -ton constitute a complete, unmodified surname (Preston, Washington, Worthington) whose -ton was acquired hundreds of years ago. Not one of the place-names with -town constitutes a complete, unmodified surname. ${ }^{20}$ But many of the latter consist of a surname plus -town (Andersontown, Hagerstown, Twiggtown).

Maryland's place-names with -town were for the most part composed in America. However, not all of Maryland's place-names in -ton are from England. Avilton and Carrollton are American combinations, the former perhaps from the rare surname, Auvil. ${ }^{21}$ Denton is from Governor (E)den plus -ton. Such exceptions, where -ton makes a new American name, support the generalization that -town in an American place-name is usually a mark of the New World and recent times. ${ }^{22}$

13 Rev. Patrick Woulfe (Irish Names and Surnames, Dublin 1923, p. 269): "... de Mora" is an "old Anglo-Norman surname in Ireland." Even though these names may be Irish, OE MOR is the origin.

14 However (as Reaney says), all the modern surnames (Pool, etc.) may also come from Paul.

15 TDr Baltimore: seven Newports.

16 TDr Talbot Co.: four Shaws.

17 There appears to be an unexplained confusion of Briscoe with Biscoe.

$18 \mathrm{TDr}$ Baltimore: four Wellham ${ }^{8}$.

19 Heads 1790: ten Cawoods.

20 Note, however, that in the 19 place-names with Town (e.g., Town Creek) listed in Coordinates 1962, there is the possibility that one or more is from the surname Town(e). 21 TDr Garrett Co., 1963: John B. Auvil.

${ }^{22}$ Statistics in this regard would be interesting. "G. H. Armstrong (Origin and Meaning of Place Names in Canada, Toronto, 1930) discusses only five Canadian places in town. 
(II) WİC (OE loan word from Lat. vicus, and the counterpart of cognate (French) -ville /vicula from Lat. vicus/) appears fairly often in British place-names as -wic/k/. Ekwall lists about 166 place-names with WIC. Of names with the cognate -ville he has only 20. Four of these 20 have their -ville from confusion with $\mathrm{OE}$ FELD; two have -ville from confusion with French -ville. Only two (Coalville, Frithville) have -ville as the suffix of an English word (coal, FYRHTH/E). The remaining 12 are double names (e.g., Acton Turville), whose second parts are from French local surnames ultimately derived from places in France, usually Normandy.

In Maryland there are relatively few places with WĪC (Gaz. Md. 1904: Ardwick, Brunswick, ${ }^{23}$ Fenwick Creek, Warwick, Warwick River $\left.^{24}\right)$. Of these only Fenwick Creek and Warwick are surname derivatives. On the other hand, there is a disproportionate number of Maryland place-names in -ville. Gaz. Md. 1904 lists 146! Only several of these are complete, unmodified surname derivatives (e.g., Barrellville, Turville Creek). The names in -ville that are not complete, unmodified surnames - almost the totality - were probably composed in modern times without attention to idiomatic English place-name construction (i.e., with -ton). Such names in other states have been criticized. A. Howry Espenshade notices disapprovingly the Pennsylvania towns "formed by the addition of the ubiquitous and inappropriate French -ville to the family name.... ."25

The foregoing details suggest that Maryland names composed of the less common OE place-name elements (e.g., DENU, DUN, EG, ROD, SCEAFA) are probably from England, derived either from place-names there, or from the local surnames such place-names gave rise to. Maryland surname derivatives, however, with the more common, more easily recognized elements (e.g., BURH

${ }^{23}$ Although Brunswick is the Anglicized from of German Brunschweig, German -schweig is from the same Lat. vicus that gives the English (loan) element WİC.

${ }^{24}$ Warwick, Cecil Co., is /wśr wík/. There is one Warrick in TDr Dorchester

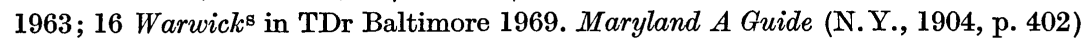
mentions Warwick Fort Manor, 1720. It overlooks Secretary Creek. Jones (Revised History of Dorchester County, 1925, p. 90) indicates that Warwick River was once known as Secretary Creek, so named for Henry Sewall, Secretary of Maryland in 1661.

${ }^{25}$ Pennsylvania Place Names (State College, Pa., 1925), p. 205. 


\section{2} Hamill Kenny

/-burg/, LAND, WUDU /-wood/, TUN /-town/, -ville) are in some instances artificial. In any event, in the interpretation of such names, potential ambiguity increases the risk of confusion and error.

\section{Ambiguity: Kinds and Instances}

Some OE place-name elements (e.g., HAEFEN) do not appear in the list of the chief Old English elements of Maryland's placenames from surnames, because it is not clear, at least on the face of it, that the available examples really contain surnames. In the case of HAEFEN, Whitehaven, the example of its occurrence, may commemorate either a surname Whitehaven, ${ }^{26}$ or Whitehaven, the Cumberland (England) town and seaport. This ambiguous situation, illustrating how the names of English towns can (in their American derivatives) be confounded with the local surnames they gave rise to, has a significance for Maryland quite beyond the question of which Old English place-name element is illustrated. Correct personal place-name credit is at stake. Here it would be an easy choice to attribute Whitehaven to its English place-name counterpart, though it might really have been named for one or another $M r$. Whitehaven. The truth is, to pursue the example, that there is probably no such surname as Whitehaven. Clayton Torrence settles the matter by stating that near the beginning of the eighteenth century Whitehaven was established "through the influence of Col. George Gale" (d. 1712), of Whitehaven, Cumberland, England. ${ }^{27}$

An analysis of the kinds of ambiguity one encounters in Maryland place - names that may have come from surnames shows that there are, in general, five ambiguous situations:

(I) The first of the ambiguous situations is when a local surname is spelled exactly like the English place-name that gave rise to it, thus leaving the inquirer, until he obtains the local history, quite in the dark about whether the place-name (e.g., Barton, Romney Creek, Warwick) is from a local surname or from an identically spelled English village that gave rise to the local surname. Consider, for instance, Maryland's Warwick (three) and War-

\footnotetext{
${ }^{26}$ The word looks every inch a surname when one considers (TDr Baltimore) Whitefield, Whiteford, Whitehill, Whitehurst, Whiteside, Whitestone ....

${ }_{27}$ Old Somerset on the Eastern Shore of Maryland (Richmond, 1935), p. 415, n.
} 
wick River. In England (besides the shire) one finds two villages named Warwick. Was the Maryland Warwick named from one of the English villages? Or was it named for a Warwick, probably the Earl of Warwick? A statement by Andrews makes the surname origin more likely for Maryland: "In 1634, Parliament, dominated by Puritans, could not let the distant Maryland province rest in peace. It passed an ordnance making the Earl of Warwick Governorin-Chief and Lord High Admiral of all the plantations in America."28

Sometimes a place-name is identical in spelling to both a local surname and an English or other foreign place so well known that it would seem reasonable, without further question, to assume that the place-name is not from a surname but from the place. Examples are Boston Creek, Cardiff, and Ireland Creek. Without local knowledge one would suppose that all of these are from the well known places they seem to name. Cardiff, however, could be from the rare surname; Heads 1790 lists Wm. Cardiff. In view of two entries (Bostain, Boston) in TDr Charles and St. Mary's Counties, and some 80 instances of Boston in TDr Baltimore, it seems likely that Boston Creek, St. Mary's County, is from a surname, and not from Boston, Massachusetts (or Boston, Lincolnshire, England). Ireland Creek $^{29}$ remains in doubt, since Ireland is often a surname (TDr Baltimore: 60 occurrences).

(II) The second ambiguous situation is when a Maryland placename embodies a word that can (owing to identical or almost identical spelling $)^{30}$ be either a surname or a common noun (even an $\mathrm{OE}$ place-name element). Examples are Bear Branch, Trappe (Talbot Co.), and Loveville. ${ }^{31}$ Bear (probably from OE BAER "pasture," or OE BEARU "grove, wood") ${ }^{32}$ was the surname of 14 Marylanders in 1790 (Heads). It is also the name of an animal so abundant (in 1732) on Maryland's Eastern Shore that there was a law to encourage its extinction. Fortunately, the locality of most

${ }^{28}$ History of Maryland: Province and State (Repr. 1965, Introd. Radoff), p.108, citing Eggleston.

${ }^{29} \mathrm{It}$ is probably a corruption of Island Creek. See Gaz. Md. 1941.

30 Thus (Frederic Emory, Queen Anne's County Maryland, 1950, p. 352) Reed's Creek appears in 1768 as Reedy Creek.

31 Note also Love Point, Queen Anne's Co. Emory (op. cit., p. 45) lists Robert Love as a member of the Queen Anne's Co. militia, American Revolution. He points out that "Love Point, Kent Island, was known as such in 1694."

32 This surname (Baer, etc.) can, of course, be German. 
of the places in bear (branches, creeks, hills, hollows, runs) makes it likely that they are not from surnames. One can be quite sure, for instance, that Bear Cabin Branch, Bear Camp Branch, and Bear Pen Run are for the animal. But what of Bear Point, Harford County? As for Trappe (Talbot Co.), it was (like Bear) an early surname. Heads 1790 lists William Trap, Baltimore Co. In TDr Baltimore 1969 there are 21 instances of Trapp; there is one case of the trade name Trappe on "Trappe Road." Emory clarifies the ambiguity of Trappe (Talbot Co.) when he states (p. 10): "A 'wolf trap bridge' mentioned in a deed of July 14th, 1724, would seem to explain the origin of ... Trap or Trappe as used to designate a certain portion of Talbot County." 33 But does this also correctly explain Trappe in Wicomico and Worcester Counties, and "Trappe Road" (TDr), Baltimore ?34 Loveville, by the way, is from one $\mathrm{Kin} / \mathrm{g} /$ sley Love, who organized the post office here in 1895 and "named the territory for himself." 35

(III) Ambiguity arises because many given names and surnames are spelled alike. Examples are Hel(l)en (St. Mary's and Calvert Counties) and Israel Creek (Frederick and Washington Counties). Heads 1790 lists Captain Jersey Hellen for Prince George's County. TDr Md. \& D. C. Suburbs has one Helen; TDr Baltimore has four Hellens. Helen, St. Mary's Co., is from Helen Hancock, daughter of Oscar Hancock, the first postmaster. ${ }^{36}$ The Calvert County Hellen names (Hellen, Hellen Creek, Hellen Gut) are ascribed by Charles Stein to Nathaniel Helen, probably a Huguenot, "founder of one of Calvert County's historic families," who immigrated to Maryland in $1671 .^{37}$

As for Israel Creek (Washington Co.), Israel was the surname of Midshipman Israel (Washington Co.), who was killed in the ex-

${ }^{33}$ Despite Emory, the origin of Trappe (Talbot Co.) is still questioned. $A$ Tourist's Guide (Talbot Co. Chamber of Commerce, 1968) states that some suppose that Trappist monks once had a farmhouse monastery here. Others think that a tavern, "The Partridge Trap," was responsible for the name.

${ }^{34}$ Speaking of Trap(pe), Worcester Co., Archives, XLII (1744, p. 472) has "... at the head of Assateague Creek at a place commonly called the Trapp."

35 John Sherwood, "Cupid Now Bypassing Loveville," Washington Star, Feb. 14, 1970, A-7.

36 Frank Henry, "Helen and Its History," Baltimore Sun, Nov. 5, 1961/Magazine/, p. 20.

${ }^{37}$ A History of Calvert County Maryland (Baltimore, 1960), p. 65. 
plosion of a fire ship in Tripoli Harbor, September 4, 1804. ${ }^{38}$ The name was also a given name, to judge by such entries (Heads 1790) as Israel French, Israel Johnson, Israel Pusey, Israel Swann, and Izrel Merrick. Israel French (Heads 1790: Frederick Co.) appears to be a mistake for Israel Friend. Grove states (p. 368) that the will (1803) of Adam Link describes a tract, "Four Friends," on Israel Creek, Frederick Co. ${ }^{39}$ William B. Marye ${ }^{40}$ cites a 1734 survey that mentions (in connection with Israel Creek, Frederick Co.) "...a bounded white oak standing near Israel Friend's Mill Road...." Israel Creek, Washington County (cf. Midshipman Israel), probably contains the surname. Israel Creek, Frederick County, is probably for Israel Friend (French, mistakenly, in Heads 1790).

(IV) Ambiguity can arise because of the phonetic and orthographical similarities of some surnames either to each other or to an orthographic double (e.g., Carville/Station/, Queen Anne's Co.). Wellhams (Anne Arundel Co.), for instance, looks as though it embodies the surname, Wellham. Yet, though there are four Well$h_{a m}$ in TDr Baltimore, there are no Wellhams in TDr Anne Arundel. On the other hand, TDr Anne Arundel has ten Wilhelms. Is Wellhams, the village, from Wellham or Wilhelm? Carville, a station on an almost disused railroad near Centreville, is pronounced /kárv! /, like the surname Carvel; there are two Carvels in TDr Kent and Queen Anne's Counties. Today only a few carloads of wheat are sometimes moved, but in the past there has been railroad activity here. Did Carville, then, arise from Car plus -ville? Doubt is cast on such a theory by the fact that the similarly spelled Carville's Corner Pharmacy (Annapolis) is run by Carville Hopkins, who was named for a Judge Carville because his father wanted him to be a lawyer. Happily, all doubts about the origin of Carville Station which could be from $C a r$ plus -ville, from the given name Carville (Carvel), or from the surname Carville (Carvel) - are settled by Emory's mention (p. 278) of Carville's Station and (p. 554, for 1869) "the road from Carville's Corner to Centreville." 11 But it is not easy to determine which of the following (mentioned by Emory) is commemorated by the name: Edmund Carville, Kent Island parishioner; T. M. Carville, almshouse trustee; John Carvil, Kent

38 William Jarboe Grove, Carrollton Manor, Frederick County, Maryland (1921).

39 Op. cit. $\quad{ }^{40}$ "The Old Indian Road," III (Md. Hist. Mag., XV./1920/383).

41 Frederic Emory, Quenn Anne's County, Maryland (Baltimore, 1950). 
County, 1706 commissioner for towns and town lands; Thomas R. Carville, one of the incorporators of the Bank of Centreville (1874) and County Commissioner (1875).

(V) Ambiguity sometimes results when a place-name is spelled with elements that raise doubt as to whether it is a surname derivative or a fabricated landscape name. The complications arise from the essentially descriptive nature of some place-name elements. Sometimes it is just one of the elements of a name that contributes to confusion, such as the -land of Suitland. Sometimes it is all of the elements, as with the fair and -bank/s/ of Fairbanks (Talbot Co.). Suitland, however, makes little sense as "suit" land (though it could refer to a lawsuit); and there is no such surname as Suitland. On the other hand, six Suits are listed in Heads 1790. This name, then, is probably the surname Suit plus -land. Fairbank(s) is more annoying, particularly in the light of Gannett's statement that (in the United States) "Fair" is a name used with "brook," "land," "port," etc., to indicate "an attractive appearance." Gannett remarks that Fairfield (Conn., etc.) was a "fair field," and that Fairport, N.Y., is a "fair port" on the Erie Canal. The question as to Fairbank(s), Md., can only be settled by local inquiry. The present writer (by such inquiry, March 4, 1970) learns from Mrs. Evelyn Fairbanks Lednum (Tilghman, Md.) that her great grandfather owned all "of the land on which the village of Fairbanks is located." In lieu of inquiry, there is perhaps enough verification of the surname origin of Fairbank(s) in the fact that Heads 1790 lists seven families of Fairbank (and one Fairbanks), and that Passano ${ }^{42}$ mentions the family name Fairbanks for Talbot County in connection with the Evans family chart. Other instances of this sort of ambiguity are abundant. There is always the possibility that such names as Castlehaven, Greenfield, Greenhurst, Highfield, Highland, Westwood, and Woodland - though they may already exist as surnames (e.g., Greenfield, Highfield/Heads 1790/, Highland ${ }^{43}$ /Heads 1790/, Woodland) - are artificial.

42 Eleanor Passano, An Index of the Source Records of Maryland (Baltimore, 1967).

43 It seems unlikely that Baltimore's Highlandtown (el. $100 \mathrm{ft}$.) is from the surname Highland (TDr Balt: Highland, 2; Highlander, 2). Howard (The Monumental City/Baltimore, 1873/, p. 279) speaks of "Highland Park," one mile from Baltimore, on the Liberty or Windsor Mill road, "rising to an elevation of about 500 feet above tide...." 


\section{Ethnological Ambiguities}

Place-names, separately and in groups, often indicate the racial background of the communities they name. The abundance of Maryland place-names that embody Old English place-name elements and English local surnames - especially in the older Maryland counties - defines the overall ethnic composition of the state to be English. This is in spite of many ambiguities, which nevertheless are not abundant enough to nullify the ethnological truth of a long list. With single place-names, however, there can be gross error. What, for instance, is the ethnical significance of the fact that in Allegany County there is the village, Poland, and that in TDr Allegany there are 27 Polands? Evidently Poland was named for the Poland family. But only local research will reveal whether the Polands are Polish. ${ }^{44}$

In general, the ambiguities of possibly ethnic place-names are of two kinds. First, there is the suggestive similarity in spelling that makes a place-name containing a surname sometimes seem to have an ethnological meaning that it does not have. Breton Bay (St. Mary's Co.), for instance, suggests that a Breton once settled there. The original settler, however, was William Bretton, Gentleman, who came to Maryland from England in 1637. Since the etymology of his surname is probably OE BRAEC "copse, thicket" (Brēc plus tūn; cf. Bratton), Breton Bay does not at all mean Brittany or a Breton. The name, indeed, is very English! Holland Cliff (Calvert County) is another false witness in this regard, for its origin here is English. The $-s$ in an alternate form, Hollands Cliff, indicates that it is a surname. ${ }^{45}$

Second, racial surnames often have an inherent semantic ambiguity. Reaney (xlvii-xlviii) remarks: “... a Gaelic-English surname [does not] prove descent. A Celtic surname may be borne by one with very little Celtic blood in his veins. Whilst a man with an Anglo-Saxon name may be almost a pure Celt." He points out that Irish names that once would have indicated ethnic groups were sometimes changed to English. MacSeain became Johnson; O'Bruic became Badger (Reaney, xlix-xlx). "Such surnames were carried by Irish immigrants to England, Scotland and America

\footnotetext{
14 Smith, p. 196, points out how Poland can be an English surname.

45 The $-s$ is not a reliable sign of a surname derivative.
} 
where they were often corrupted in pronunciation and spelling thus adding endless complications to the difficulties of tracing their origin." Reaney's remarks are borne out by such entries in Maryland Death Records (Baltimore Co., 1860) as Frederick English born in Ireland; Robert Scott, born in Ireland; etc. Speaking generally, the Israel names (Frederick and Washington Counties) - whether they are from surnames or from given names - are, obviously enough, too old to have any connection with Israel! If Pagan Point ${ }^{46}$ has an ethnic significance, it is hardly because it refers to the pagan Indians, but because, being related (as a surname) to OF paien (Pain, Pagan ?), it is ultimately a French surname. To cite a final case, there is no surname Irish in TDr Talbot. In TDr Anne Arundel there are two listings of Irish (also, Heads 1790, Mary Irish; TDr Baltimore, six Irish). What is the significance, then, of Irish Creek (Talbot Co.)?

Evidently one ethnic surname does not make an ethnic community. However, some ethnic significance can be given to groups of place-names that seem to embody ethnic surnames. The following group of obvious German surname derivatives points to the somewhat numerous German element of Garrett County: Feik Run, Gortner, Koontz Run, Krug. Similar evidence is found in Washington County, where there is the cluster: Ernstville, Fiery, ${ }^{47}$ Fiery Siding, Funkstown, Hagerstown, Mondel, ${ }^{48}$ and Spilman. Yet it seems to the present writer that such place-names as Germantown, Old Germantown, and New Germany - which are probably not from surnames ${ }^{49}$ at all - are more significant.

The close linguistic relationship between German and English causes the two languages to have many similar surnames. This increases the ease with which some German surnames can be changed ${ }^{50}$ to English (Braun-Brown, Freund-Friend, Müller-Miller,

46 Archives (XIX, 1693-97, p. 263, p. 434): Cap't/sic/ Peter Pagan (Paggan).

47 Gaz. Md. 1941. Biographical Cyclopedia of Representative Men of Maryland and District of Columbia (Baltimore, 1879) lists Hon. Nathaniel Fiery (s. of Joseph Fiery), born in Hagerstown in 1843 "of German extraction."

48 Mondel = Mandel ?

49 German Creek is misleading. Record of Deaths Md., 1860: Mary, Joseph, F., Josephine, Nancy German.

${ }_{50}$ The surnames of non-English immigrants were frequently modified, translated, or even completely changed. Death Records (Md. 1870) show that George Apple, of Allegany Co., was born in Hesse Cassel. Other examples (Rec. of Deaths, 
Schmidt-Smith, etc.). Beck can be either an English or a German surname; cf. Beck Branch. Even the German surname Meier, ${ }^{51}$ which takes such forms as Mayer, Mayr, Maier, Mair (fr. Lat. major), is sometimes identical in spelling to the Meier and Mayer of English (Reaney, p. 218). However, it is often Jewish, and can even be French. To determine the correct ethnological significance of Myersville (Frederick Co.) might well require an appeal to genealogy. However, I have learned from Sallie Marker (letter, Myersville, March 12, 1970) that Myersville is a German community (incorporated in 1904), and probably takes its name from "the several Stottlemyers families" that came here. The earliest settler was perhaps James Stottlemyer (1742).

The full pursuit of surname-place-name ambiguity leads the researcher to wonder whether there are in Maryland some surname derivatives with Amerindian and African ethnic significance. Unhappily, for ethnic considerations, most Negro surnames are from English and European surnames. Lately, a news story by Jack Kneece $^{52}$ brought out the fact that West Street, Vienna, Va., was named for Thomas West (grandfather of 96-year-old William West, Fairfax County's oldest living former teacher), the first Negro to own property in Vienna, Va. I know of no such clear case for Maryland. The Indians of Maryland, in some instances, acquired the surnames of the settlers. Archives, XIX (1693-1697, p. 384) mentions ". . a certain Indian called King Calvert." Mr. Philip Proctor (of Mechanicsville, St. Mary's Co.), who claims Southern Maryland Indian ancestry, has told the present author that the surname Proctor (TDr St. Mary's and Charles Counties: 38 entries) is commonly borne by the mixed Indians called "Wesorts." Proctors Wharf appears to be the only Maryland place-name with the surname Proctor (Coordinates 1962). Though Proctors Wharf is in Charles County it does not appear likely that it was named for a "Wesort." As for surname derivatives of Black significance, one finds 47 instances of the surname Barnes in TDr St. Mary's and Charles Counties. Curiously, this abundance of so English a sur-

1860) are Andrew Smith, Charles Ambrose, Godfrey Winters (all of Baltimore Co.), born in Germany. Rec. of Deaths (Carroll Co., 1860) lists Jacob Stevenson, born in Germany.

${ }^{51}$ Albert Heintze, Die Deutschen Familien Namen (Halle, 1882), p. 218.

52 “At 96 a Slave's Son Is Reflective," Washington Star, March 5, 1970. 
name does not so much indicate the presence of the Englishman as it does the presence of the black man. George Morgan Knight, ${ }^{53}$ telling that Abraham Barnes [Tudor Hall, 1760] willed freedom to his 300 slaves on the condition that they take his name, declares that, for this reason, there are in St. Mary's County "more negroes ... [with] the surname Barnes than any other, according to the voting books ...." Coordinates 1962 lists Barn Cove, Barnes Corner, Barnes Cove, Barnes Landing (v.), Barnes Landing Creek, Barnesville (2), and Barns Cove. Of these, only Barnes Cove is in St. Mary's County. As for ethnical significance other than English, these names are faceless.

\section{Relative Importance}

Questions as to their relative importance arise when one considers how perplexing it sometimes is to resolve the ambiguities of surname derivatives, and how futile it often is, in obscure cases, to seek the necessary local history. One sometimes wonders, in short, whether such and such a name is worth the effort. Considered objectively, the fact that Frostburg was named for Meshach Frost is no less important than the fact that Emmitsburg was named for William (Samuel ?) Emmit(t). ${ }^{54}$ However, there are subjective considerations, both special and general, that make the origin of some names more important than others:

(I) Places themselves, varying in their significance because of size and location, give more or less importance to the surnames they embody. Thus, owing to the greater consequence of Hagerstown, it is perhaps more important to know that its name is from Jonathan Hager than to know that Friendsville bears the name of John Friend. And since Savage River is an appreciable inland stream that has given its name to Savage Mountain and (indirectly) to Mt. Savage (p.v.), it is perhaps more important to know that Thomas Savage ${ }^{55}$ gave the river its name than to know that

53 Intimate Glimpses of Old Saint Mary's (Washington, 1942), p. 35.

54 Gannett (p. 119) and the Britannica, eleventh ed. (IX, 343-44) attribute the name to William Emmitt. James A. Helman (History of Emmitsburg, Maryland...। Frederick, 1906/, pp. 45-46, p. 55) attributes the name to Samuel Emmit, nationality Irish.

55 A news story, "Mayo Party Surveyed. . Potomac 200 Years Ago," Piedmont W.Va.) Herald, Oct.29,1936, refers to him as "the Blind George Savage." I follow 
Pope's Creek is for Nathaniel Pope. However, places that are unimportant today can leap into importance tomorrow. For instance, it has lately become of interest to know something about the Gilbert of Gilbert Swamp Run. ${ }^{56}$ This is because Gilbert Swamp is going to be drained, and an ecological furore has arisen over whether the drainage will disturb the area's famous yellow perch. ${ }^{57}$

(II) Regardless of the importance of the places they are connected with, some surname derivatives are valuable in themselves because they name key pioneers, state officers and politicians, founders, celebrities. On this basis, Moores Run (Allegany Co.), for Edward Moore, is less important than Rawlings, for Colonel Moses Rawlings, of the American Revolution. Cresaptown, named for the sons of the pioneer, Daniel Cresap, is perhaps more important than *Surrattsville (now Clinton), named for the family of Mrs. Mary E. Surratt, who was hanged in connection with the murder of Lincoln. Beyond a certain point, of course, the evaluation of importance becomes a matter of opinion.

(III) Some place-names from surnames have unusual linguistic importance because of the rarity of those surnames. Mockler ${ }^{58}$ has remarked, "It is not impossible that early American surnames, some of which are extinct in Britain, preserve old words and meanings not otherwise recorded." Perhaps in Maryland, whose colonial immigrants were mainly English, there are place-names that embody English surnames rare today in both Britain and the United States (e.g., Carvel, Hollofield, Punger /Pungers Creek/ Rover, Towsers Branch, Woodland). German examples are Finzel and Uncle.

(IV) Place-names from surnames gain more value when it turns out that they have an ethnological significance. The facts, however, must in each case be verified. Ramsay declares, "Taken in large numbers, the personal names... will show unmistakably the predominance of certain national elements, such as French or Spanish, British, Irish, German, in the population...." Even a

the form of the name given in West Virginia Historic and Scenic Highway Markers (Charleston, 1937).

56 Heads 1790 lists no Gilberts for Charles Co., 26 for all of Maryland. TDr Charles and St. Mary's Cos., 1963 has one Gilbert.

57 Washington Star, Feb. 17, 1970, D-4.

58 W. E. Mockler, "Surnames of Trans-Allegheny Virginia 1750-1800" I, Names 4: 1 (March, 1956), 7. 
single name sometimes has ethnic weight; but this is no field for guesswork. Hack, in Hacks Point (Cecil Co.) has the appearance of an English surname. Dieter $\mathrm{Cunz}^{59}$, however, indicates that George Hack, of Hack's Point (Cecil Co.), naturalized in 1676 (?), was a German.

\section{What Policies Are Indicated?}

T. M. Pearce ${ }^{60}$ has declared, "...not all place names are of sufficient interest to justify including them in a dictionary for public use..." Myron Quimby ${ }^{61}$, in his popularization, confines himself to "communities with unusual names," and skips "intentionally" over what he calls "the Jonesvilles and the Smithtowns." Ramsay however, never suggesting relative importance, advises his students, "If the place was named for an early settler, or some other local resident, give any facts you can discover about him... his occupation, trade, or profession and exact place of residence, where he came from and when he arrived in the neighborhood, and the date of his death."

Only in a very detailed, lengthy study could one do all that Ramsay recommends, not to mention that in many cases the local history of a surname derivative has been completely lost. A placename study, of course, is not a biographical dictionary. It should not play the role of the local historian by setting forth needless details of town, county, and state history. Should the investigator, then, approximate Ramsay? And what should be his policy in a place-name paragraph meant solely to discuss the origin and onomastic significance of a surname derivative, such as one of those of Maryland?

These questions are to some degree answered by the following three recommendations:

(I) It is not unpardonable to leave out an occasional Smith or Jones. Theoretically, however, all such names have equal importance. Statistics hinge on the completeness of a place-name canon. Genealogical accuracy is a consideration. Place-namehonor - a sort of immortality - should be assigned where it is due. If one

\footnotetext{
59 The Maryland Germans A History (Princeton, 1948), p. 41.

Ko New Mexico Place Names (Univ. of New Mexico Press/1965/).

Х ${ }^{61}$ Scratch Ankle. U. S. A. (New York/1969/).
} 
includes Boonsboro (for George and William Boone), why should one not include Zittlestown (for the Zittle family)? An effort should be made, then, to enter and explain a fully representative selection of a region's surname derivatives.

(II) All surname derivatives that are in the least suggestive of ambiguity should be challenged. A name such as Coon Ridge (Washington Co.) could be casually dismissed as meaning the raccoon, whereas it may commemorate a person or family by the name of Coon (Heads 1790, Washington Co.: Henry Coon, Jacob Coon). Coon's Ferry (Montgomery) is certainly from the surname. A further example is Roach Point, where one needs local knowledge to avoid the mistake of attributing the name to the fish (the roach) if it means $M r$. Roach, and to avoid attributing it to Mr. Roach if it means the fish. ${ }^{62}$ The names of national figures are often identical to common local surnames. In Maryland the surname, Franklin, is numerous. Thus it is necessary to consult local history to determine whether Franklin (Allegany Co.) is from a local person or family, or from Benjamin Franklin. ${ }^{63}$

To avoid the pitfalls suggested by the foregoing, it should regularly be ascertained about place-names supposed to contain surnames (a) that a surname is really involved; and (b) that it has been attributed to the right person. The initials and dates of the person should be stated (when discoverable), and also the time the name was given. Very important, of course, are authorities and references. They should be given to the extent they are known.

(III) Though the surnames involved in these place-names should not be treated as though they themselves were the subject of study, a statement should be made, where pertinent and possible, as to their ethnic significance. Thus, in an item on Fells Point (for William Fell) it should be pointed out that Fell, Fells is usually English (Reaney). This would greatly increase a study's ethnological value.

${ }^{62}$ Though the roach is a European fish, it appears that, in America, the "golden shiner" minnow is sometimes called a roach.

${ }^{63}$ Register... United States... 1833 (Phila., 1834): Franklin, Md. (p.v.). Gaz. Md. 1941 : Franklin Hill, Franklin Mines. Thomas and Williams (History of Allegany County, Maryland/1923/, I, 455) mention "Franklin Coal Co.," in operation here in 1869 . 


\section{Conclusion}

Place-names from surnames are place-names from people. Because such names are particularly vulnerable to ambiguity, each name needs special study. Human nature is such that more interest attaches to surname derivatives than to less personal place-names. After all, man is more interested in himself than in hills, fields, creeks, runs, and branches. The conscientious place-name researcher, to establish truth and to assign honor fairly, must not shrink from a discussion of the "Jonesvilles" and the "Smithtowns." Such names represent the bold, venturesome pioneer. In some cases he was our ancestor. He made this country, and he should, when it is possible, be completely and correctly credited with the places that bear his name. These injunctions, of course, are ideal; practice will always fall short!

Annapolis, Maryland

\section{NECROLOGY}

Elliot V. K. Dobbie, Columbia University, April 9, 1970.

Bertram L. Hughes, St. Lous, Mo., April 30, 1970.

Michael S. Vartanoff, Bethesda, Md., March 28, 1970. 